\title{
Rainfall Interception by Midgrass, Shortgrass, and Live Oak Mottes
}

\author{
T.L. THUROW, W.H. BLACKBURN, S.D. WARREN, AND C.A. TAYLOR, JR.
}

\section{Abstract}

Interception, as a function of simulated rainfall intensity and duration, was determined for a midgrass [sideonts grama (Bouteloua curtipendula (Michx.) Torr.)] and a shortgrass [curleymesquite (Hilaria belangeri (Steud.) Nash)]. In addition, the redistribution of natural precipltation via plant interception was determined for live onk (Quercus virginiana Mill.) mottes. Interception storage capacity for sideoats grama and curleymesquite was 81 and $114 \%$ of dry weight, respectively. This difference was attributed to physical characteristics of the species and their respective growth forms. However, because sites dominated by sideoats grama had more standing biomass $\left(3,640 \mathrm{~kg} \mathrm{ha}^{-1}\right)$ than sites dominated by curleymesquilte $\left(1,490 \mathrm{~kg} \mathrm{ha}^{-1}\right)$, it was estimated that a sideoats grama dominated site had an interception storage capacity of $1.8 \mathrm{~mm}$ compared to curleymesquite dominated site with an interception storage capacity of $1.0 \mathrm{~mm}$. Based upon precipitation event size and distribution for the study site at the Texas Agricultural Experiment Station near Sonor, Texas, the estimated interception loss for curleymesquite dominated sites was $10.8 \%$ of annual precipitation, compared to $18.1 \%$ interception loss for sideoats grama dominated sites. Only $54 \%$ of the annual precipitation reached mineral soil beneath the oak mottes as throughiall or stemflow. The remainder of the precipitation was intercepted by the motte canopy or litter layer and evaporated. Due to the water concentratins effect of stemflow, soil near the base of trees received about $222 \%$ of annual precipitation. Soil at a distance greater than approximately $100 \mathrm{~mm}$ from a tree trunk received only $\mathbf{5 0 . 6 \%}$ of annual rainfall. Individual tree canopy width, height and depth measurements were insignificant predictors of stemflow and throughfall. Interception, throughiall and stemflow, expressed as percent of storm precipitation, were well-defined curvilinear functions.

Key Words: standing crop, rainfall intensity, rainfall duration, throughiall, stemflow

Availability of water is one of the predominant factors influencing rangeland productivity. It has been demonstrated that plant interception can substantially influence the water budget of an area (Clark 1940, Kittredge 1948, Helvey and Patric 1965, Delfs 1967, Corbett and Crouse 1968, Douglass 1983, Hibbert 1983, and Seastedt 1985).

To date, grass interception research has been characterized by a diversity of techniques that includes simulating rainfall on grass clippings arranged in a wire basket (Beard 1956), sealing the soil surface with Neoprene and measuring the amount of runoff (Corbett and Crouse 1968), measuring the amount of water that reached a collection area below grasses that had been cut at the soil surface and placed on a screen over a funnel (Clark 1940), or the

\footnotetext{
Authors are presently range research scientist, Louis Berger International, P.O Box 2954, Mogadishu, Somalia; hydrologist/research leader, USDA-Agricultura Research Service, Northwest Watershed Research Center, 270 South Orchard, Boise, Ida. 83705; watershed research scientist, USA-CERL, Environmental Division, P.O. Box 4005, Champaign, IIl. 61820; and superintendent of the Texas Agricultural Experiment Station at Sonora, Tex. 76950. Send reprint requests to the fourth author. At the time of research, the first and third authors were graduate research assistants and the second author was professor of Watershed Management, Department of Range Science, Texas A\&M University.

Published with the approval of the director, Texas Agricultural Experiment Station as TA-21726. Supported in part by USDA, Soil Conservation Service RCA Specia Study No. 58-7442-4-2800 and USDA, Science/Education Grant No. 83-CRSR-2 2268. The authors gratefully acknowledge the assistance of personnel of the Texas Agricultural Experiment Station at Sonora, Tex. Special thanks to S.L. Hennefer for typing the manuscript.

Manuscript accepted 24 April 1987.
}

use of interceptometer pans (Clark 1940). Clark (1940) reported that interception losses by big bluestem (Andropogon gerardi Vitman.), a tall grass 560 to $910 \mathrm{~mm}$ in height, ranged from 57 to $84 \%$ of simulated rainfall applied at intensities of 3 to $25 \mathrm{~mm}$ for a duration of 30 minutes. He likewise determined the interception losses by buffalograss [Buchloe dactyloides (Nutt. Engelm.], a shortgrass, to be 17 to $74 \%$ of simulated rainfall applied at intensities on 3 to $13 \mathrm{~mm}$ for a duration of 30 minutes. Haynes (1940) estimated interception loss by Kentucky bluegrass (Poa pratensis L.) to be $56 \%$ of annual precipitation. Beard (1956) estimated interception loss from a South African grassland composed primarily of Themeda spp. and Cymbopogon spp. to be about $13 \%$ of annual rainfall. Kittredge (1948) estimated net interception of a California grassland composed primarily of Avena spp., Stipa spp., Lolium spp. and Bromus spp. to be about $26 \%$ of annual precipitation. Few attempts have been made to express interception as a function of biomass or cover, even though these factors have been identified as major sources of potential variation (Clark 1940, Haynes 1940).

It has been documented that some tree species intercept a greater percent of annual precipitation than others (Kittredge 1948, Helvey and Patric 1965, Helvey 1971). Generally, coniferous and hardwood (with leaves) species'interception loss averages about 30 and $13 \%$, while stemflow is approximately 3 and $5 \%$, respectively of the annual precipitation. Canopy interception by shrubs has been documented by relatively few studies (Tromble 1983) with interception losses ranging from 4 to $50 \%$ depending upon canopy density and species. Shrub interception studies have been mostly restricted to California chaparral species (Hamilton and Rowe 1949) or juniper (Skau 1964, Young et al. 1984) whose interception losses averaged about 13 and $18 \%$, respectively, of annual precipitation. Litter interception is largely determined by the amount of litter accumulated and its drying rate (Helvey and Patric 1965). Maximum water holding capacity of eastern forest litter, expressed as a percent by weight, has been reported to range from $215 \%$ (Helvey 1964) to 263\% (Bernard 1963).

Watersheds where vegetation cover has been converted from shrub to grasses have yielded significantly greater amounts of water in areas receiving more than $457 \mathrm{~mm}$ of annual precipitation (Burgy and Pomeroy 1958, Corbett and Crouse 1968, Hibbert 1983). Increased runoff associated with conversion of shrub cover to grass cover has generally been attributed to lower water use by grasses when compared to shrubs. However, investigators have documented that interception can be an important loss in addition to transpiration losses (Thorud 1967, Rutter 1967, Nicolson et al. 1968, Waggoner et al. 1969 and Murphy and Knoerr 1975).

Sideoats grama [Bouteloua curtipendula (Michx.) Torr.] and curleymesquite [Hilaria belangeri (Steud.) Nash] are the dominant bunchgrass and shortgrass over much of the Edwards Plateau region of Texas. Live oak (Quercus virginiana Mill.) is a schlerophylous, evergreen, low-growing tree that covers 20 to $50 \%$ of the rangeland on the Edwards Plateau. The objectives of this study were: (1) to determine the relationship of interception storage to storm intensity and duration for bunch-type midgrass (sideoats grama) and sod-type shortgrass (curleymesquite) growth forms; and (2) to characterize interception by live oak motte canopy and litter, and the degree to which throughfall and stemflow redistribute the water reaching the soil. This project was part of a larger 
effort to determine the influence of vegetation manipulation on the water budget.

\section{Study Area}

Research was conducted at the Texas Agricultural Experiment Station, located $56 \mathrm{~km}$ south of Sonora at $632 \mathrm{~m}$ elevation, in Edwards and Sutton Counties, Texas $\left(30^{\circ} \mathrm{N} ; 100^{\circ} \mathrm{W}\right)$. The rolling stony hill topography that characterizes the station is typical of the Edwards Plateau. Annual median precipitation, 1918-1984, was $438 \mathrm{~mm}$ and ranged from $156 \mathrm{~mm}$ to $1,054 \mathrm{~mm}$. The annual mean precipitation for the same period was $609 \mathrm{~mm}$. Such a wide disparity between the mean and median annual precipitation is indicative of the annual variability caused by frequent droughts and occasional very wet years. Cool-season precipitation is generally the result of frontal storms, whereas warm-season precipitation occurs from brief, intense convective storms. The mean frost-free period is 240 days.

Currently, the region's vegetation is a mixture of grasses, forbs, and woody species. Woody plant distribution is often clustered, with dominant species being live oak, ashe juniper (Juniperus ashei Buchh.), and honey mesquite (Prosopis glandulosa Torr. var. glandulosa). The dominant midgrass is sideoats grama and the dominant shortgrass is curleymesquite. Oak mottes at the study site were characterized by a dense monospecific canopy with sparse undergrowth and heavy litter accumulation.

\section{Methods}

\section{Midgrass and Shortgrass}

During July, 1984, monospecific, 300 by $300-\mathrm{mm}$ squares of sideoats grama and curleymesquite sod were excavated and placed into a square wire mesh container of the same size. The plants were actively growing, and the standing crop was typical of natural variation of the study site. The container held the soil and rooted portion of the grasses together and thus maintained the original configuration of the grasses. These grass sample units were taken to the laboratory where simulated rain was applied within minutes of collection. Moisture content of excavated grass sample units was determined by clipping adjacent representative samples of grass, weighing the samples, drying them at $60^{\circ} \mathrm{C}$ for 48 hours and reweighing them.

Water was applied to the grass sample using a drip-type rainfall simulator (Blackburn et al. 1974). Ten sample plots of each grass species for each rainfall intensity/duration combination were used. The following combinations of rainfall intensity and duration were used: intensity of $25 \mathrm{~mm} \mathrm{~h}^{-1}$ for a duration of $1,2.5,5,7.5,10,15$, and 20 minutes; intensity of $114 \mathrm{~mm} \mathrm{~h}^{-1}$ for a duration of $0.3,0.6,1$, $2.5,5,7.5$, and 10 minutes; and 5 minutes duration with the intensity of $25,50,90,114,150$, and $175 \mathrm{~mm} \mathrm{~h}^{-1}$. The rainfall intensity/duration combinations were selected to establish interception response curves and to determine the interception storage capacity of the grasses. At the conclusion of the simulated rainfall, the samples were carefully placed in a freezer $\left(-46^{\circ} \mathrm{C}\right)$ that was adjacent to the rainfall simulator. Water intercepted by the grasses was frozen within 5 minutes. The frozen grasses were clipped at the soil surface while in the freezer, and then weighed. The grass sample was composed of live and dead standing crop. Detached litter lying on the soil surface was not included in the sample. The grass was then dried at $60^{\circ} \mathrm{C}$ and weighed again. The difference between frozen grass weight and dried grass weight represented the sum of the plant water content and intercepted water. Water intercepted by the grass standing crop (expressed as percent of grass dry weight) was calculated by subtracting the percent moisture content of the representative grass sample (estimated from the moisture content data collected from grass of the same species growing adjacent to the excavated grasses) from the percent plant water content and intercepted water retained by the grasses after simulated rainfall. An analysis of variance was conducted to determine species' differences in interception of simulated rainfall.
Duncan's multiple comparison test was used to separate the means (Steel and Torrie 1980). Significance levels were determined at $p \leq 05$.

Bimonthly vegetation cover and standing crop data were collected over a 7-year period (1978-1984) on a pasture that was continuously grazed at a moderate rate (8. I ha/ AU/yr) (Thurow et al. 1986). These data provided mean standing crop estimates for curleymesquite and sideoats grama dominated sites. Meteorological data collected at the study site over a 10-year period (1974-1984) were used to develop a mean distribution of annual size and frequency of precipitation events. The interception functions developed with simulated rainfall were than applied to the natural vegetation and meteorological data to estimate the interception rainfall retained by curleymesquite and sideoats grama-dominated sites.

\section{Live Oak Mottes}

Data were collected from 4 live oak mottes which were representative of the size and shape of mottes on the study site. Twenty rainfall events were sampled over a period of 1 year. Storm size, duration, and intensity were determined from a recording and a standard nonrecording raingage located in a grass interspace approximately $15 \mathrm{~m}$ from the live oak mottes. Throughfall, stemflow, and litter interception were measured in each motte. Canopy interception loss was determined by subtracting throughfall and stemflow measurements from total precipitation. Water infiltration rate into motte soil was determined by Thurow et al. (1986) using a rainfall simulator.

Throughfall was determined by randomly placing 40 receptacles beneath the canopy of the oak mottes. The receptacles were 250 $\mathrm{mm}$ tall and had a diameter of $150 \mathrm{~mm}$. Throughfall in each receptacle was measured volumetrically within 12 hours of each rainfall event. The percent foliar cover above each receptacle was measured by ocular estimate as an observer stood directly over the receptacle and peered upward through a cylinder $1,000 \mathrm{~mm}$ long and $150 \mathrm{~mm}$ in diameter. Absolute cover was measured by calculating the mean number of hits recorded when extending a telescoping rod through the canopy from 5 locations within each receptacle.

Stemflow was measured by fastening aluminum collars around 46 randomly selected live oak trees. The collars were affixed to the trunks with silicone sealant at a height of $600 \mathrm{~mm}$. The collars funneled stemflow into storage bottles. Stemflow was measured volumetrically within 12 hours of each storm and expressed as a percent of precipitation. Trunk diameter at breast height (dbh), canopy circumference, canopy depth, and tree height were measured for each collared tree.

Litter accumulation was determined on $30,0.5-\mathrm{m}^{2}$ plots randomly located within the oak mottes. Large branches and other bulky organic debris that would have distorted the litter estimate were excluded. For the purpose of this study, the term "litter" is defined as that part of the motte floor that lies above mineral soil, being composed of a layer of relatively unaltered organic litter, a layer of partly decomposed organic matter, and a humus layer that could be visually separated from the mineral soil. A drying rate curve similar to those expressed by Blow (1955) and Helvey (1964) was determined by collecting and weighing field samples of litter each day at noon for a period of 15 rain-free days following a storm of $55 \mathrm{~mm}$ which had saturated the litter layer. Thus, field capacity measured as water content (percent by weight) of litter 1 day after rain (Blow 1955) and minimum water content were determined. The maximum water holding capacity of the litter was determined by placing a preweighed sample of the litter profile into a 10,000 $\mathrm{mm}^{2}$ tray with a $2-\mathrm{mm}$ wire mesh bottom, weighing the tared sample, applying $80 \mathrm{~mm}$ of water by simulating rainfall at a rate of $10 \mathrm{~mm} \mathrm{hr}^{-1}$, and weighing the sample after drainage had ceased (approximately 30 minutes later). Rainfall amounts of 5, 10, 20, and $\mathbf{4 0} \mathrm{mm}$ were also simulated. Ten samples for each simulated rainfall amount were collected. Rainfall was applied using a driptype rainfall simulator (Blackburn et al. 1974). This method pro- 
vided data needed to construct a curve of litter interception as percent of storm intensity.

All statistics were calculated using SAS Institute Inc. (1985) procedures. Regression analysis was used to determine the degree of association between variables. Analysis of variance techniques were conducted to determine if differences between oak mottes existed for throughfall, stemflow, or litter accumulation (Steel and Torrie 1980). Significance levels were determined at $p \leq 0$.

\section{Results and Discussion}

\section{Midsrases and Shorternses}

Curlymesquite and sideoats grama represent 2 different grass growth forms. Curlymesquite is a stoloniferous species with flat blades (50-200 mm long and 1-2 $\mathrm{mm}$ wide) that are pilose (1-2 mm long). The slender stolons grow horizontally along the soil surface and are characterized by wiry internodes and pubescent nodes. In contrast, the sideoats grama at the study site is characterized by a bunch growth form that has flat to subinvolute blades $(20-300 \mathrm{~mm}$ long and 2-4 mm wide) with scattered hairs only along the blade edges. During the 7-year period (1978-1984), curleymesquite dominated sites had a mean foliar cover of $56 \%$ and a mean standing crop of $1,490 \mathrm{~kg} \mathrm{ha}^{-1}$. Sites dominated by sideoats grama had a mean foliar cover of $62 \%$ and a mean standing crop of $3,640 \mathrm{~kg}$ $\mathrm{ha}^{-1}$.

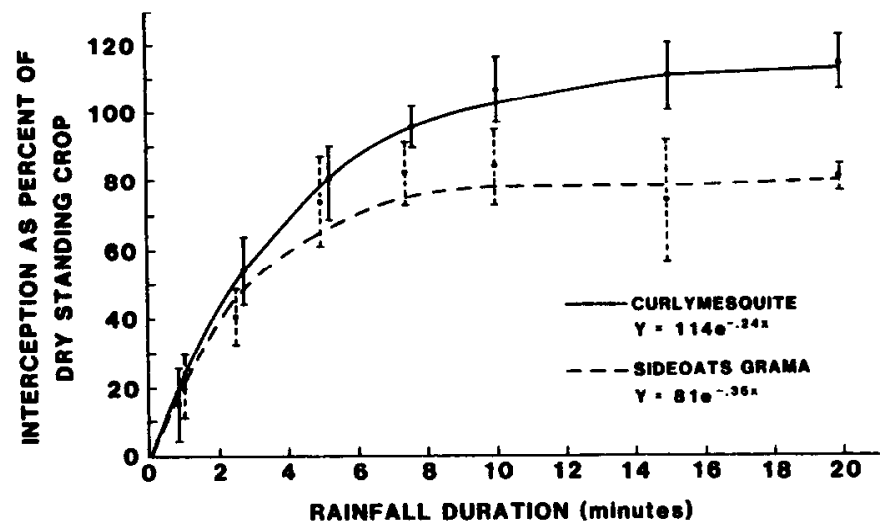

Fig. 1. Interception as percent of dry standing crop across time for a rainfall intensity of $25 \mathrm{~mm} \mathrm{hr}$. Vertical bars indicate confidence limits ( $\leq \leq 05$ ). Interception response curves denote predicted dependent variables from an intuitive model based on the exponential saturation growth function.

The interception storage capacity of curlymesquite ( $114 \%$ of dry weight) was significantly greater $(p \leq .05)$ than the interception storage capacity of sideoats grama ( $81 \%$ of dry weight) (Figs. 1-3).

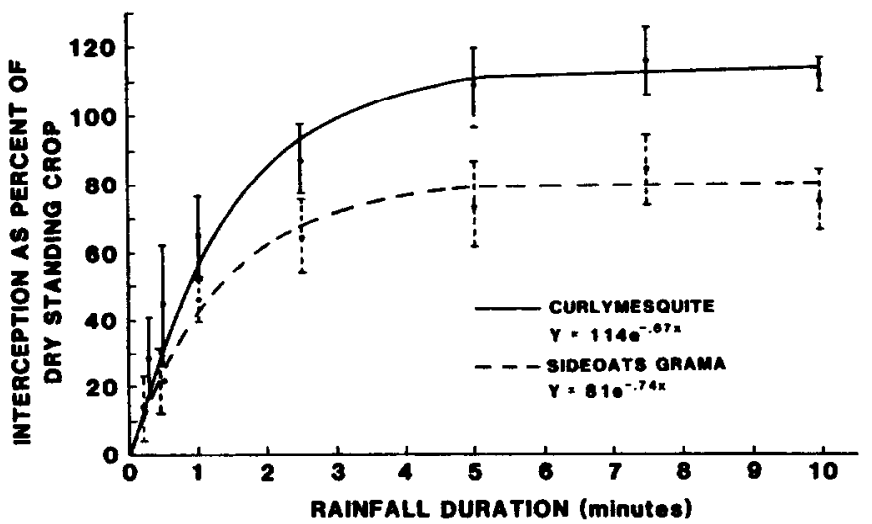

Fis. 2. Interception as percent of dry standing crop across time for a rainfall intensity of $114 \mathrm{~mm} \mathrm{hr} \mathrm{r}^{-1}$. Vertical bars indicate confidence limits ( $p<05$ ). Interception response curves denote predicted dependent variables from an intuitive model based on the exponential saturation growth function.

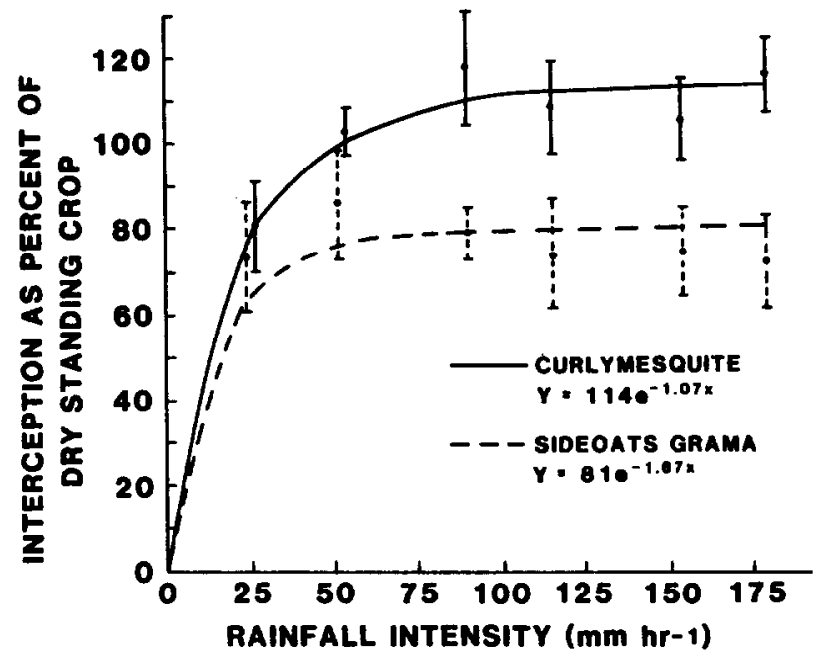

Fis. 3. Inteception as percent of dry standing crop after a rainfall duration of 5 minutes. Vertical bars indicate confidence limits $(p<.05)$. Interception response curves denote predicted dependent variables from an intuitive model based on the exponential saturation growth function.

It is hypothesized that the pilose blades and the horizontal growth form of curlymesquite aided water retention, compared to the relatively vertical smooth blades of sideoats grama. The length of time needed to reach the storage capacity of the grasses varied with rainfall intensity. Interception storage capacity per unit dry weight was exceeded after 8 minutes for the $25 \mathrm{~mm} \mathrm{~h}^{-1}$ rainfall event (Fig. 1) and after 5 minutes for the $114 \mathrm{~mm} \mathrm{~h}^{-1}$ event (Fig. 2). Likewise, storage capacity was exceeded by storm intensity of $40 \mathrm{~mm} \mathrm{~h}^{-1}$ for 5 minutes (Fig. 3).

The greater potential for curlymesquite foliage to intercept water is offset by a lower standing crop production potential when compared with that of sideoats grama. Consequently, the interception storage capacity was significantly greater for sideoats gramadominated sites $(1.8 \mathrm{~mm})$ than for curlymesquite-dominated sites $(1.0 \mathrm{~mm})$. These values are comparable with the estimated storage capacity of $1.1 \mathrm{~mm}$ for a mixture of fescue (Festuca spp.) and soft chess (Bromus mollis L.) (Burgy and Pomeroy 1958). Based on the 10-year mean storm size distribution of the study site, interception loss from curlymesquite-dominated sites would be $10.8 \%$ of annual precipitation compared to $18.1 \%$ loss from sideoats gramadominated sites. Interception loss corresponds to the amount of grass standing crop and would thus be greatest during the growing season and lowest during the dormant season.

\section{Live Oak Mottes}

Most rainfall at the study site occurred as convective or frontal storms which were characteristically intense, short duration events. Analysis of data showed no significant differences for stemflow or throughfall attributable to duration or intensity of storm. Seasonal variability was not evident due to the evergreen nature of the live oak foliage. Thus, storm size was the principal determinant of stemflow and throughfall. In addition, there were no differences in stemflow, throughfall, or litter accumulation among the 4 mottes monitored in this study; therefore, data from the 4 mottes were pooled.

The mean foliar cover above the throughfall receptacles was $42 \%$ and ranged from 3 to $85 \%$ with a standard deviation of 25.3. Mean absolute cover was $124 \%$ and ranged from 5 to $400 \%$ with a standard deviation of 107.6. For small rainfall events, percent throughfall was approximately the inverse of percent foliar cover (Fig. 4), implying that most of the water striking foliage was held within the canopy. As storm size increased, percent throughfall increased due to drip loss from the canopy, and eventually became fairly 


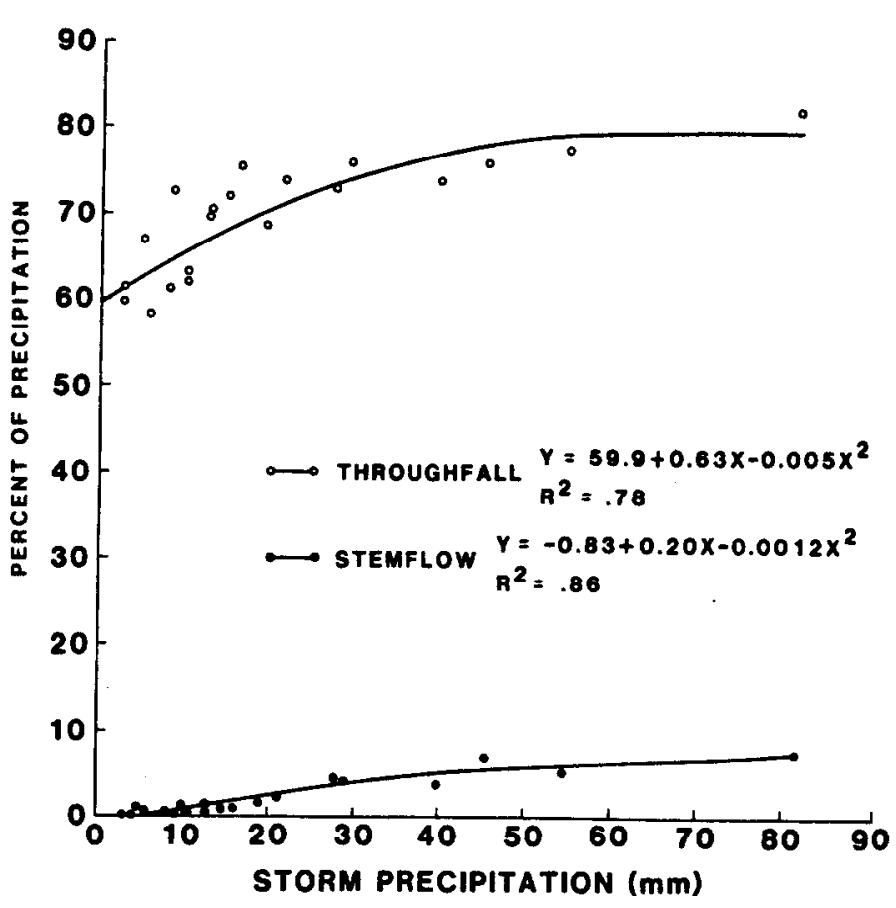

Fic. 4. Percent of precipitation within oak mottes occurring as throughfall or stem flow as a function of storm size, Edwards Plateau, Texas.

constant. Throughfall was poorly correlated with either the percent foliar $\left(R^{2}=.13\right)$ or percent absolute cover $\left(R^{2}=.18\right)$ above the throughfall receptacles indicating that other, unmeasured variables such as drip-points played an important role in determining throughfall.

In much of the early literature, throughfall was reported as a percentage of gross rainfall, a term that is of little value when storm size distribution is not presented. More recent studies use linear regression or curvelinear functions to illustrate the percent of gross rainfall that occurs as throughfall across a range of storm sizes. The curvelinear approach is more descriptive when comparing the relative importance of the various factors reflecting rainfall redistribution as a function of storm size. Based on a 10-year storm size distribution pattern, throughfall at this study site will account for approximately $73.3 \%$ of annual rainfall (Table 1 ). This value is

Table 1. Distribution of annual rainfall within oak mottes based on the 10-year average storm size distribution at the study site, Edwards Plateau, Texas.

\begin{tabular}{lcc}
\hline \hline & $\begin{array}{c}\text { Water } \\
\text { (mm) }\end{array}$ & $\begin{array}{c}\text { Percent of } \\
\text { Annual Rainfall }\end{array}$ \\
\hline Annual precipitation & 523 & \\
Throughfall & 373 & 71.3 \\
Stemflow & 17 & 3.3 \\
Canopy interception & 133 & 25.4 \\
Litter interception & 108 & 20.7 \\
Water reaching mineral soil & 282 & 53.9 \\
\hline
\end{tabular}

slightly lower than average deciduous forest estimates of 80 to $85 \%$ (Kittredge 1948, Helvey and Patric 1965). The value is similar to the 70 to $75 \%$ determined for densely crowned open-grown trees (Lunt 1934, McMunn 1935, Fraser 1956). This is consistent with the typically dense canopy of live oaks. In addition, the rigid nature of the sclerophyllous leaves may facilitate water retention since they do not droop as do most other broad-leafed species when water is applied. The dense canopy and leathery leaves of live oak are typical of many other semiarid shrubby species implying that throughfall estimates developed on eastern deciduous hardwoods may not be representative of tree growth forms in semiarid regions.

Stemflow did not begin on most trees until gross precipitation exceeded $7 \mathrm{~mm}$, but increased thereafter in a pattern similar to throughfall (Fig. 4). The mean dbh of the 46 collared trees was 90 $\mathrm{mm}$ (range $23-229 \mathrm{~mm}$; SD-48 mm). The mean canopy diameter was $1.6 \mathrm{~m}$ (range $0.6-4.2 \mathrm{~m} ; \mathrm{SD}=0.9 \mathrm{~m}$ ). The mean tree height was $3.8 \mathrm{~m}$ (range $1.7-7.0 \mathrm{~m} ; \mathrm{SD}=1.2 \mathrm{~m}$ ). These values were poorly correlated with stemflow $\left(R^{2}<0.2\right)$. The canopy volume and indices composed of various combinations of the measured variables also yielded low coefficients of determination $\left(R^{2}<0.28\right)$. The greatest coefficient of determination was obtained by correlating stemflow with an index composed of canopy depth divided by canopy width $\left(R^{2}=.28\right)$. This index provides a general quantification of canopy shape (i.e., gradient ranging from tall and narrow to short and broad). This index to stemflow is intuitively sound since tall, narrow canopies have the potential to funnel more water down the trunk compared to broad, shallow canopies that have a horizontal branching structure with many potential drip points. Unmeasured variables such a branch angles, drip points along branches, bark roughness, lichen growth on bark, etc., are apparently important factors for predicting individual tree stemflow. Nevertheless, mean stemflow of the sample population was very predictable and the quadratic curve which fit the data accounted for a significant portion of the sample variation. The stemflow at the study site was $3.3 \%$ of annual rainfall (Table 1). This value is comparable to estimates summarized by Kittredge (1948) and Helvey and Patric (1965).

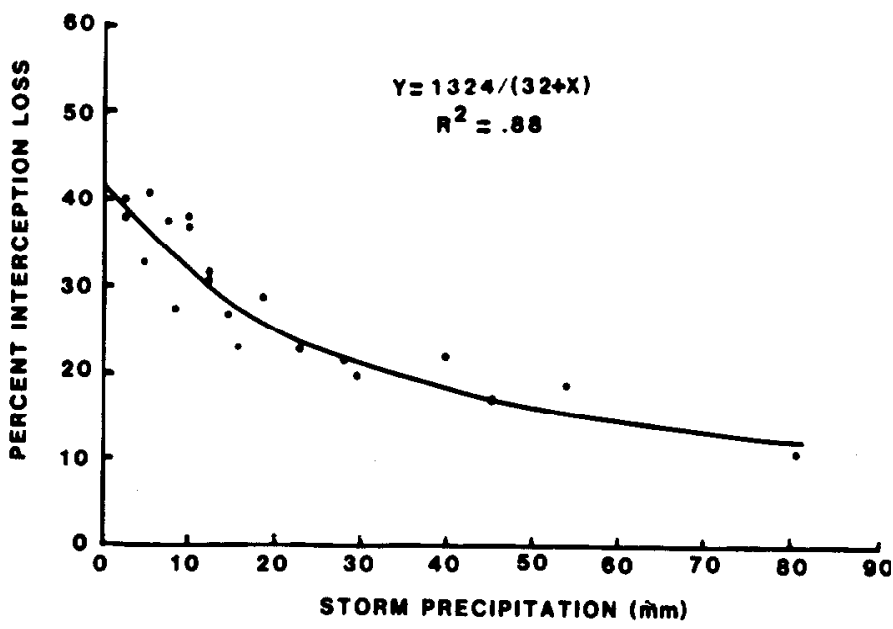

Fis. 5. Interception loss by oak matte canopy as a function of storm precipitation, Edwards Plateau, Texas.

Litter biomass under oak mottes averaged $41,300 \mathrm{~kg} \mathrm{ha}^{-1}$. This degree of accumulation is relatively high when compared to litter accumulation in most other regions of the country (Helvey and Patric 1965). The high accumulation of litter under live oaks in the study region may be attributable to the sclerophyllous oak leaves which are resistant to decomposition, the semiarid climate and low moisture availability which deter microbial decomposition, and the absence of fire. The $210 \%$ maximum interception by litter was similar to previously reported values of $225 \%$ (Blow 1955) and $215 \%$ (Helvey 1964). The minimum water content of litter was $17 \%$ which is similar to reported values of $20 \%$ (Blow 1955), $22 \%$ (Semago and Nash 1962) and lower than $40 \%$ reported by Helvey (1964).

The percent of precipitation intercepted by litter and oak canopy from storms of various sizes is illustrated in Figures 5 and 6 . The percent precipitation reaching mineral soil based on a series of storm sizes is shown in Figure 7. On the average, $53.9 \%$ of the annual rainfall actually reaches the soil, $25.4 \%$ is lost by canopy interception and $20.7 \%$ by litter interception (Table 1). Distribution of water reaching the soil under the oak motte is variable. Stemflow concentrates water at the base of the trunks. Mean water 


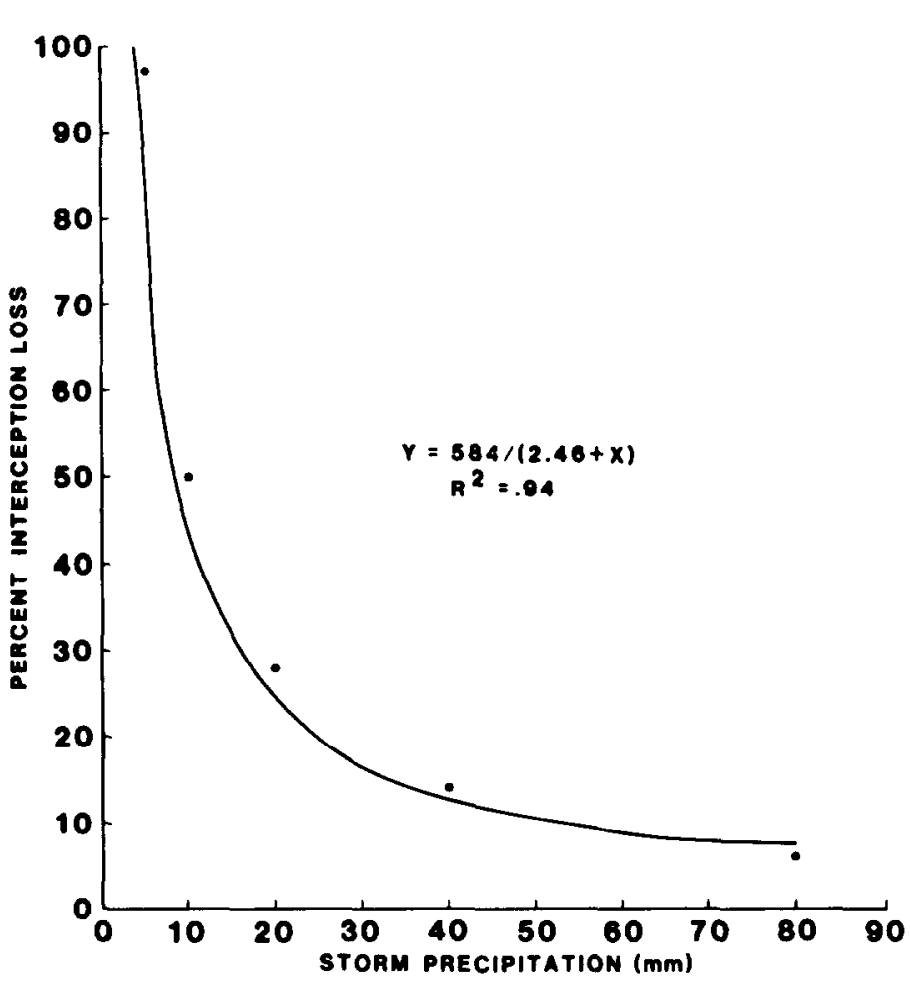

Fis. 6. Interception loss by oak motte litter without a canopy as a function of storm precipitation, Edwards Plateau, Texas.

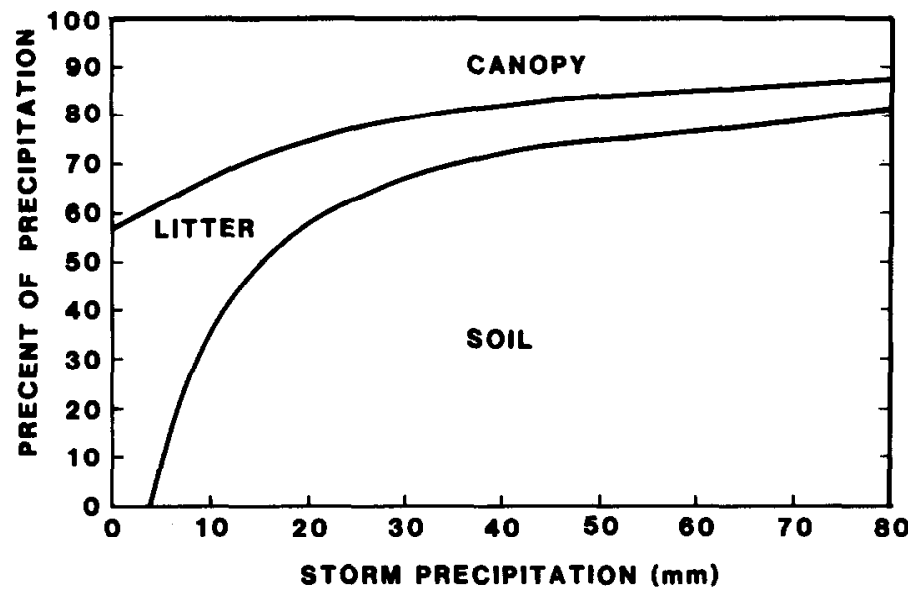

Fic. 7. Precipitation within oak mottes reaching the mineral soil or evaporated as canopy or litter interception as a function of storm precipitation, Edwards Plateau, Texas.

infiltration rate into oak motte soil was $199 \mathrm{~mm} \mathrm{hr}^{-1}$ (Thurow et al. 1986). Based on a mean stemflow of $955 \mathrm{ml}$ per storm event, a radius of about $100 \mathrm{~mm}$ around the trunk would be needed to fully accommodate infiltration of the stemflow. This means that a 100 $\mathrm{mm}$ radius of soil around the tree would receive approximately $222 \%$ of annual precipitation, whereas the soil under the canopy farther than $100 \mathrm{~mm}$ away from the trunk would receive only $53.9 \%$ of annual precipitation. This concentration of water at the base of the trees represents an effective water harvesting factor that could be an important mechanism of water and nutrient supply. Areas away from the tree trunks receive less rainfall, making it a drier environment for plant establishment and growth.

Interception data collected on live oak mottes (the dominant shrub species on the study site) confirm the intuitive expectation that shrub cover intercepts more than grasses. Live oak motte interception loss by the canopy was $25.4 \%$ of the annual precipitation. This implies that canopy interception losses from the shrub component may be 2.4 times greater than losses by the grassdominated interspaces. Infiltration rate under oak mottes $(199 \mathrm{~mm}$ $\left.\mathrm{hr}^{-1}\right)$ is greater than for midgrass sites $\left(162 \mathrm{~mm} \mathrm{hr}^{-1}\right)$ or shortgrass sites $\left(109 \mathrm{~mm} \mathrm{hr}^{-1}\right.$ ) (Thurow et al. 1986). Shifts in the kind and amount of vegetation on the Edwards Plateau have the potential for greatly influencing the hydrologic water balance and, to a large extent, determining the amount of rainfall retained, lost, or yielded from a watershed.

\section{Literature Cited}

Beard, J.S. 1956. Results of the mountain home rainfall interception and infiltration project on black wattle, 1953-1954. J. South African Forestry 27:72-85.

Bernard, J.M. 1963. Forest floor moisture capacity of the New Jersey pine barrens. Ecol. 44:574-576.

Blackburn, W.H., R.O. Meeuwis, and C.M. Skau. 1974. A mobile infiltrometer for use on rangeland. J. Range Manage. 27:322-323.

Blow, F.E. 1955. Quantity and hydrologic characteristics of litter under upland oak forests in eastern Tennessee. J. Forestry 53:190-195.

Burey, R.H., and C.R. Pomeroy. 1958. Interception losses in grassy vegetation. Trans. Amer. Geophys. Union 39:1095-1100.

Clark, O.R. 1940. Interception of rainfall by prairie grasses, weeds and certain crop plants. Ecol. Monogr. 10:243-277.

Corbett, E.S., and R.P. Crouse. 1968. Rainfall interception by annual grass and chaparral...losses compared. USDA Forest Serv. Res. Paper PSW-48.

Delfs, J. 1967. Interception and stemflow in stands of Norway spruce and beech in West Germany, p. 174-185. In: Proc. Internat. Symp. on Forest Hydrol. Pergamon Press, New York, N.Y.

Douglass, J.E. 1983. The potential for water yield augmentation for forest management in the Eastern United States. Water Res. Bull. 14:351-358.

Fraser, D.A. 1956. Ecological studies of forest at Chalk River, Ontario, Canada, 2, Ecological conditions and radial increment. Ecol. 37:777-789.

Hamilton, E.L., and P.B. Rowe. 1949. Rainfall interception by chaparral in California. California Dep. Nat. Resour. Div. Forestry.

Haynes, J.L. 1940. Ground rainfall under vegetation canopy of crops. J. Amer. Soc. Agron. 32:176-184.

Helvey, J.D. 1964. Rainfall interception by hardwood forest litter in the southern Appalachians. USDA Forest Serv., Southeast Forest Exp. Sta. Res. Paper 8.

Helvey J.D. 1971. A summary of rainfall interception by certain conifers of North America. In: Proc. Biol. Effects in the Hydrologic Cycle, 3rd Internat. Seminar of Hydrol. Professors, Lafayette, Ind.

Helvey, J.D., and J.H. Patric. 1965. Canopy and litter interception of rainfall by hardwoods of Eastern United States. Water Resour. Res. 1:193-206.

Hibbert, A.R. 1983. Water yield improvement potential by vegetation management on western rangelands. Water Resour. Bul. 19:375-381.

Kittredge, J. 1948. Forest influences. McGraw-Hill Book Co., New York, N.Y.

Lunt, H.A. 1934. Distribution of soil moisture under isolated forest trees. J. Agr. Res. 49:695-703.

MeMunn, R.L. 1935. The distribution of rain under an apple tree. Amer. Soc. Hort. Sci. Proc. 33:95-98.

Murphy, C.E., and K.R. Knoerr. 1975. The evaporation of intercepted rainfall from a forest stand: An analysis by simulation. Water Resour. Res. 11:273-280.

Nicolson, J.A., D.B. Thorud, and E.I. Sucofr. 1968. The interceptiontranspiration relationship in white spruce and white pine. J. Soll and Water Conserv. 23:181-184.

Rutter, A.J. 1967. An analysis of evaporation from a stand of scots pine, $p$. 403-416. In: Proc. Internat. Symp. on Forest Hydro. Oxford, England. Pergamon Press.

SAS Institute Inc. 1985. SAS user's guide: Statistics. Version 5 Edition. Cary, N.C., SAS Institute Inc.

Seastedt, T.R. 1985. Canopy interception of nitrogen in bulk precipitation by annual burned and unburned tallgrass prairie. Oecologia 66:88-92.

Semago, W.T., and A.J. Nash. 1962. Interception of precipitation by a hardwood forest floor in the Missouri Ozarks. Univ. of Missouri Agr. Exp. Sta. Res. Bull. 796. 
Skau, C.M. 1964. Interception, throughfall and stemflow in Utah and alligator juniper cover types of Northern Arizona. Forest. Sci. 10:283-287.

Steel, R.G.D., and J.H. Torrie. 1980. Principles and procedures of statistics. McGraw-Hill, New York, N.Y.

Thorud, D.B. 1967. The effect of applied interception on transpiration rates of potted ponderosa pine. Water Resour. Res. 3:443-450.

Thurow, T.L., W.H. Blackburm, and C.A. Taylor, Jr. 1986. Hydrologic characteristics of vegetation types as affected by livestock grazing systems, Edwards Plateau, Texas. J. Range Manage. 39:505-509.
Tromble, J.M. 1983. Interception of rainfall by tarbrush. J. Range Manage. 36:525-526.

Waggoner, P.E., J.E. Begg, and N.C. Turner. 1969. Evaporation of dew. Agr. Meteorl. 6:277-230.

Young, J.A., R.A. Evans, and D.A. Eash. 1984. Stemflow on western juniper (Juniperus occidentalis) trees. Weed Sci. 32:320-327. 